\title{
Should Overqualification among Employees be Addressed?
}

\author{
Besmira Lahi
}

University of Tirana

\begin{abstract}
This research paper is aiming to explore the problems deriving to employees from overqualification feelings. Why should we speak about overqualification in times where too much demands for education and qualification are being required to employees in the market? What are the reflections of overqualified employees at work? Could overqualification be reduced if organizations should better hire employees?All these research questions have been part of the study supported from the exploration of the theoretical concepts of psychologists referring as well to the reality of the employees in Albania crossing the poor trade market and experiencing several psycho-social problems such as stress, low self-esteem, lack of job satisfaction and chances of turnover. This research article ends up imposing another research question: Should overqualification be considered a social problem which needs to be addressed and oriented even to organizational and clinical psychologists? Recommendation are given to offer orientation and to intervene in this cause: more overqualified employees would bring more psychological problems to individuals. They should be well treated and oriented from clinical psychologists and even to organizational psychologists dealing with recruitment and hiring of the overqualified, especially when the job market is weak and the people feel less satisfied with their jobs.
\end{abstract}

Keywords: overqualification, hire people, employees, organizations, psychologists

\section{Introduction}

This article is focused on a subject that attracted the interest of the author because of the widely used concept of overqualification among many hiring units in private companies and the dislike for employing the overqualified. Literature has payed serious attention to overqualification too, mostly seeing it as a negative problem in times where the job market is weak and does not really offer too much possibilities of employment and chances of promotion regarding career and payment.

Can we speak about overqualification in a country like Albania running decades of instable job market and at the same time to a crush in education and qualification? Could schooling be considered one of the origins of overqualification because of the raised expectations individuals get at school?

Could overqualification feelings be reduced by having a better recruitment of employees from the start?

What do overqualified employees reflect so that these problems be addressed?

Exploration of theories and other studies related to overqualification has been done in order to put up an orientation for the organizational psychologists regarding recruitment, hiring and even to clinical psychologists regarding the reflections of overqualification.

\section{Is schooling causing effect on overqualification?}

It may seem weird somehow to speak about overqualification if we consider the high demands to education that especially young ages are imposed to. For a psychologist it is a matter of interest to analise if the demands to education and qualification become one day causes of problems deriving of thee. There is a connection and sometimes even a misunderstanding of the education and qualification term. According to Dorn, D. Souza-Poza,A.(2010) education is only one of the several individual skill components. We can consider education as the road towards qualification, but sometimes 
not really due to wrong or incorrect measurements of the individuals' achievement at school. According to the Oxford Economic Papers (2010) whatever the relationship, both concepts of 'overqualification', or 'overeducation', provide one way of describing and making us clear to understand the trends in the relationship between education and the labour market.

Many times overqualification is seen as overeducation. "In a very recent study, Walker and Zhu (2005), using a very rough measure of graduate overeducation, indicated that, post-expansion, the incidence of overeducation in the UK has risen for both male and female graduates across almost all subject groups" (in McGuinness,S.2006) and this is particularly consistent among graduates in the background of Social Science, Arts and Humanities who end up overeducated. By stressing out that some subjects of graduation are more prone to produce overqualification than others, at the same time he sees that the impacts of overeducation are potentially seen to be costly to individuals, but not only. The impacts of overqualification are seen to companies and even to the economy. It is not easy to adjust the demand with the supplies in the market and this issue has been estimated as such even for developed countries like Canada. In one study regarding the way how overqualified young adults see themselves towards their jobs, overqualification feelings are seen present in the Canadian youths, and for minimizing thee are proposed to be developed more vocational programs compared to the academic programs.

"We need to move away from the idea that a person has to be all "schooled up" in youth and make it easier for people to enter and leave the educational system at different stages of their lives. We need to continue to develop ways to assess and accept the skills acquired outside the formal educational system"1.

In the research of Russell W. Rumberger (1987) exploring this possible impact showed that surplus education as well as underutilised education are rewarded lower than the education that should be required for a job showing hints of the origins of overqualification problems. For as long as the overqualification is present throughout Europe and even far from there, the impact of overqualification should be seriously analyized and soon addressed to potentially protect individuals from being harmed from this impact because schooling and education are fueling perceptions of overqualification.

\section{Could overqualification be reduced if organizations hire people fit to the job?}

Hiring best candidates fitting to the job is one of the aims of the human resource professionals but when it comes to candidates who have got much more qualification than the job description for the position what does it happen? In one study done in Albania in 2015 regarding the selection of personnel in private companies it was found that private companies HR's did not really prefer overqualified candidates. This approach was typical for big and small enterprises reflecting hesitation to hire those candidates who could have more than described to possess as a potential candidate and even because of the fear of a possible turn over from them. According to Gera Daniel (2016) the increasing attention paid to the issue of overqualification is a result of two recent trends in modern economies referring to the growing number of graduates and to the technological development needing not very qualified personnel reducing the companies cost due to the increase of the artificial intelligence.

Meanwhile Fine (2007) speaks about overqualification from a personal prespective of employees. Overqualification is rather a measure that individuals perceive oneself possessing some qualification and characteristics that overpass the qualifications required for the job. Usually in literature overqualification is considered as a negative phenomena claimed by Erdogan,B and Bauer Talya N. (2009) because of the various negative consequences it provides to employees regarding issues such as: concept of personal evaluation, (Rosenberg, 1965), job satisfaction (Brayfield dhe Rothe 1951), turnover intentions (SPECTOR 1985), and organizational commitment to the job (Meyer, Allen, \& Smith, 1993). All these effects have been literally treated in the research paper under the overqualification dimension of perception. Authors share different approaches towards the overqualification status of an employer because of the absence of real metrics specifying the scale of overqualification. Therefore one possible orientation could be hiring people fit to the job, reducing the chances of overqualification and problems deriving from it. Framework regarding employment procedures in Albania is as young as the country's road towards the European approach. Because employing people is not a simple action: no place and no organization has given thumbs about employing the people just because hiring itself refers to a very complex endeavor. Considered in a psychological approach people are very complex; organizations either public or private are rather complex too. Organizations are made of people ruled by structures, procedures, laws effecting people's actions and even mindset.

\footnotetext{
${ }_{1}$ Pathways to the Labour Market Series - No|8 CPRN Research Report | April 2008
} 
People in a substantial view are formed by their own beliefs, attitudes: schemes of thinking and behaving, and emotions too. It is not quite simple to reframe the human nature, unlike you have to select among people the ones that are alike the profile needed: the best (more qualified) or the ones who most fit to the job.

This is the dilemma of many organizations, recruiters, psychologists and people evaluating their job offers too. Investing one's intellectual capital in an organization is taken for granted by organizations because they pay employees meanwhile on the employees' side it is rather seen as usage of their intellectual capital. In economic terms intellectual capital is easily transformed into profit for the individual, and the message has been reflected very well into people: nowadays we see an enormous interest in learning and gaining qualification, certification, attending online courses, being graduated for the second time, third time, and many other scenarios like this. Is this enormous interest really being converted into value in our job market? Before analyzing the situation in the proper time, the interest is to deeply investigate the way how recruitment of the people for being employed has been done at least during one hundred years when Albania was already an independent country and because by deepening into this scale the culture and philosophy of recruitment can emerge.

Referring to the archives of 100 years of Public Administration, a publication of the Department of Public Administration in 2012, employment of employees has been based on the likelihood of the dependent Director or Minister, which means that the Authority was the key to select the employees. There were some rules considered as criterions during the Albanian Kingdom run by King Ahmet Zogu in the thirtees' consisting of good behavior during the job, moral and energy, care and ethics reflected from behavior and oriented towards the good service, key elements seen even for career mobility. During the communist regime starting from 1945 the ideology asked for people who could all contribute for the country, however it was first seen the need to make units taking care for the staff recruitment. Today in the public sector there are specific rules on recruitment and department of human resources running for selection of candidates and assessment of performance. In the meantime, the private sector born in the first 90 's which is the least controlled regarding rules of recruitment and selection because of the request oriented towards efficiency and costs gives signs of recruitment and selection based on the profile of the candidate the company requests.

In one study committed on May-June 2015 on the way private companies recruited and selected the new employees it was found that companies selected and contacted through their the human resource unit or person in charge for recruitment and selection declared during in-depth interviews that there is a huge gap in qualification seen among all candidates mentioned by Lahi (2015). There are no qualified people looking for a job in the market and if there were more qualified people companies are ready to increase the number of employees in the market. This study proved from interview data that we cannot speak about qualified or overqualified people in the market, but there is the possibility to adapt the profile of one candidate to fit in the company throughout on the job training and adaption with the philosophy and requirements of the company, just like Campbell et al. (2001) claim about people adapting with the job due to personality characteristics, temperament to adapt with some kind of jobs among other jobs.

On the other hand, personal perception of overqualification is related to the characteristics of the candidate for the job towards the characteristics that could be measured, but from the candidates' point of view there is no place for such a measurement and calculations because they could "easily be adapted to the organization..." Johnsson,R.W\& Morrow,C.M.\& Johnson, J.G. (2002). The argument whether there should be selected the most qualified or the ones that can easily be adapted with the job and the organizational culture is still discussed. The person-job fit theory as Kristoff et al say (2006) claims that the bigger the combination between the individual and environment, the higher the achievements are, and when we speak about achievements there is no much place to talk about overqualification feelings. On the organizational point of view, overqualified candidates cannot easily be adapted with the job and subsequently are not willingly selected for the job (Edwards 1991) in the research of Finea, S.\& Nevob, B.(2008).

\section{What are the reflections of overqualified employees and who should this be addressed?}

Generally, literature treats overqualification as a negative phenomenon, mostly because overqualified employees have more negative job attitudes (Maynard, Joseph, \& Maynard,

2006) and are more likely to leave (Verhaest \& Omey, 2006). At the same time, the research of Erdogan,B and Talya N. Bauer (2009).that indicates that employees who feel overqualified perform better 
In an article by the European Centre for the Development of Vocational Training it where was analysed the issue of overqualification it has been reported that "overqualified workers are more likely to suffer wage penalties, to have a lower job satisfaction and even higher turnover than people in jobs matched to their qualifications". This happens mostly to female migrants and young workers who in many times underuse their skills and are found in jobs where no other skill could be exploited, but once this happens it frightens the perspective to stay in that job for long term leading to turnover. Even on the recruiting companies there is no such a preference for the employment of the overqualified because of the turnover chances.

"We try not to hire people who are desperate for work. If I run an ad in the paper, I get a great many résumés from overqualified people if the positions are in general service and administration. I send such people a no-interest letter, for once the labor market opens up, they will leave the company (Bewley, 1999, p. 284)."1

Results of studies suggest that there is a negative relationship between overqualification and affective commitment (Johnson et al., 2002; Lobene \& Mead, 2010; Maynard et al., 2006). Naturally employees feeling overqualified have a lower attraction and emotional connection to the job and organization they are working for, making these employees not fit to the job and having a low commitment. That is why we could speaks about the attraction-selection framework: because the lower the commitment to an organization and the lower the chances an organization has to employe the overqualified Oki,A.(2013).

Based on data from a sample of full-time employees $(\mathrm{Nr}=215)$, it was found that overqualified incumbents show undesirable counterproductive behaviors at work. According to Luksyte et al (2011) the undesirable counterproductive behavior towards work comes because of the cynism that many overqualified gain from the meaning they give to the activities at work.

The author considers even cynism as a dominant reason why overqualified workers are engaged in counterproductive behaviours Luksyte,A. Spitzmueller, Ch.Maynard,D (2011). One possible reason this happens especially when the job market is weak and the people feel themselves rather overqualified. Meanwhile it is said that overqualified people are not satisfied with their jobs (Johnson \& Johnson, 2000; Khan \&Morrow, 1991). According to Rosernberg M (1965) overqualification feelings import evaluation of the individuals towards oneself. The lack of satisfaction and the lack of personal evaluation toward onelself make individuals more prone to stress and feelings of burnout.

\section{Conclusions}

Overqualification feelings coming out of the subjective reflections of employees from their education and/or qualification in times of weak opportunities in the market have a negative impact on the overqualified by displaying stress, low self-esteem, lack of job satisfaction and chances of turnover. These reflections should be very well addressed to organizational psychologists dealing with recruitment and selection in order to take into consideration the employees feelings and the way that their status as overqualified is treated in organizations. At the same time it could be an orientation to intervene in this cause: more overqualified employees would bring more psychological problems to individuals who should be well treated and oriented from clinical psychologists and even to organizational psychologists dealing with recruitment and hiring of the overqualified.

\section{Bibliography:}

[1] Brisbois,R. Orton, L. and Saunders,R.(2008) Connecting Supply and Demand in Canada's Youth Labour Market Pathways to the Labour Market Series - No|8. CPRN Research Report

[2] Campbell, P. J. (2001) \& Knapp, J.D. Exploring the limits of personnel selection and classification. Mahwah, New Jersey, Lawrence Erlbaum pg 7-8

\footnotetext{
${ }^{1}$ Too overqualified to care: the effect of cynicism on overqualification and commitment A Thesis Presented to The Faculty of the Department Of Psychology

University of Houston Azeez Oki Dec 2013
} 
[3] Dorn, D.and Souza-Poza,A. (2010) Overqualification: Permanent Or Transitory? Oxford Economic Papers (2010), doi:10.1093/oep/gpq002

[4] Erdogan,B. and Bauer, N.T.(2009) Perceived Overqualification and Its Outcomes: The Moderating Role of Empowerment Portland State University Journal of Applied Psychology Vol. 94, No. 2, 557-565

[5] European Centre for the Development of Vocational Training pg 1-4

[6] Finea, S.\& Nevob, B.(2008)Too smart for their own good? A study of perceived cognitive overqualification in the workforce. The International Journal of Human Resource Management, Vol. 19, No. 2, February 2008, 346-355

[7] Gera, D.(2016) Legal insights: Can overqualification constitute valid grounds for dismissal? Hungary, pg1

[8] http://www.internationallawoffice.com/Newsletters/Employment-Benefits/Hungary/SchoenherrRechtsanwite/Can-overqualification-constitute-valid-grounds-for-dismissal

[9] Johnsson,R.W\& Morrow,C.M.\& Johnson, J.G. (2002). An evaluation of a POS across work settings. The journal of Psychology 136(4) 425-441 pg 427

[10] Johnsson,R.W\& Morrow,C.M.\& Johnson, J.G. (2002). An evaluation of a POS across work settings. The journal of Psychology 136(4) 425-441 pg 428

[11] Lahi,B. (2015) Personnel selection in private companies in Albania European Academic Research Vol. III, Issue 8/ November 2015

[12] Luksyte, A. Spitzmueller, Ch. Maynard, D.(2011). Why Do Overqualified Incumbents Deviate? Examining Multiple Mediators. Journal of Occupational Health Psychology

[13] 2011, Vol. 16, No. 3, 279-296. doi: 10.1037/a0022709

[14] McGuinness,S. (2006). Overeducation in the labour market. Journal of Economic Surveys. Vol. 20, No. 3 pg. 413-416

[15] Oki, A. (2013). Too overqualified to care: the effect of cynism on overqualificationn and commitment. A Thesis Presented to The Faculty of the Department Of Psychology

[16] University of Houston

[17] Publication of the Department of Public Administration (2012).100 years of Public Administration

[18] Rosenberg, M. (1965). Society and the adolescent self-image. Princeton, NJ: Princeton University Press

[19] Russell W. Rumberger,W.R.(1987).The impact of surplus schooling on productivity and earnings. Journal of

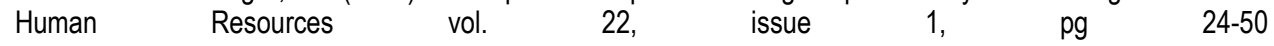
http://econpapers.repec.org/article/uwpihriss/v 3a22 3ay 3a1987 3ai 3a1 3ap 3a24-50.htm 